\title{
The logic of antinomy in religious discourse: Pavel Florensky's meta-language of theology, science and art
}

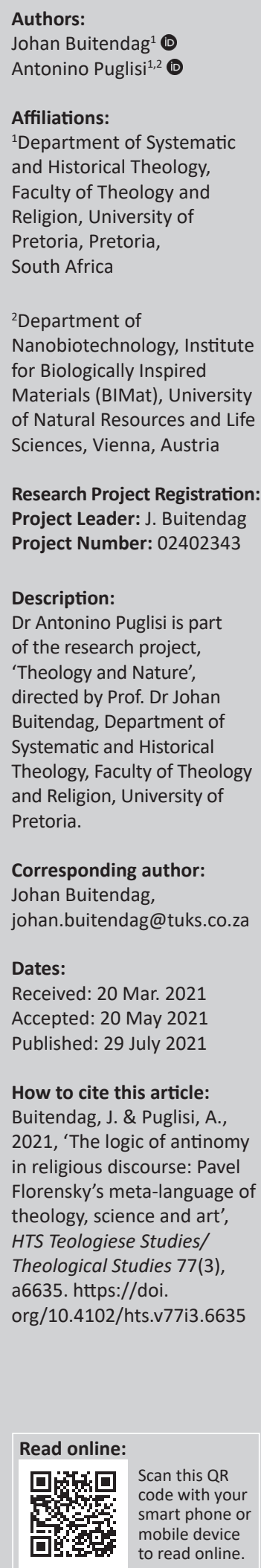

Pavel Alexandrovich Florensky is a towering figure of the 20th century. He is recognised among many significant thinkers of the world's cultural and philosophical panorama of the previous century. In the face of cultural repression and religious persecution of the Soviet regime, he preferred martyrdom to exile and not to deny his faith. The legacy of Florensky is incredibly multifaceted. His works span across the most varied fields of science and knowledge with clear competence. Florensky was the first scholar who attempted to combine Orthodox theology with modern logic. He argued that religious truth transcends known categories and Christianity tends to be antinomical. This article argues that a paradoxical notion would be more appropriate than antinomy in his thinking.

Contribution: The authors introduce Pavel Alexandrovich Florensky to Western theology and share some thoughts of this much-neglected scholar. The focus is mainly on the spiritual vision of this Orthodox priest-scientist about Nature, exploring his legacy in the theology and science debate. Florensky taught us that there is a distinctive trait of the Christian faith's attitude to Nature and that there always lies a surplus of meaning that remains inaccessible to reason alone and, therefore, Nature should be approached fundamentally with a contemplative approach and regarding a theology and science resonance, a creative mutual interaction could materialise.

Keywords: Pavel Alexandrovich Florensky; logic; science and religion; ontology; epistemology; faith; mysticism; paradox; antinomism.

\section{Introduction}

The question could indeed be raised as to why does the debate regarding theology and science continue. This debate dates back to the early 19th century when scholars of nature began referring to their work as science rather than as natural philosophy. The answer to why this ongoing debate continues is apparent: they are different in nature (ontology) and different in arriving at the 'truth' (epistemology), employing thus a different trajectory and methodology in arriving at their conclusions. Over and above this, one must bear in mind that there are many different kinds of science and many different kinds of religion.

The problem, however, arises when the differences between theology and science are underplayed or, even worse, ignored and a relationship of indifference emerges. Jürgen Moltmann, for one, mourns thus the fact that 'faith and knowledge of the world are no longer in a conflict about the truth' (Moltmann 2003:2). Robust dialogue and contestation, however, could lead to either tension or even imperialism of one of the partners. Then it is mere warfare, ${ }^{1}$ and the implication is that of a conqueror and a defeated, and subsequently a contaminated understanding of reality and negligence of the fact that both religion and science are themselves subject to cultural construction.

Thomson (2009) states this challenge appropriately when he says:

$[I] t$ lies instead in delineating more thoughtfully what each has to offer and how each may influence the other. Interaction of this kind requires scientists and religious leaders to speak beyond their disciplines and in ways that engage the wider public. (p. 177)

1.The first scholar to apply this expression was Andrew Dickson White, the young president of Cornell University in an address in 1869 with the title 'The Battle-Fields of Science' and later, in 1896, he brought out a two-volume book, History of Warfare of Science with Theology in Christendom (Numbers 2009:32).

Copyright: (C) 2021. The Authors. Licensee: AOSIS. This work is licensed under the Creative Commons Attribution License. Note: Special Collection: Theology and Nature, sub-edited by Johan Buitendag (University of Pretoria). 
The point is that it is one thing to say that everything is science, but another thing to say that science is everything. Miroslav Volf concurs with this: 'The contrast is rather between religious-political pluralism and religious totalitarianism. The position I designate here as "religiouspolitical pluralism" emerged within Christianity, but it is not the Christian position' (Volf 2011:loc. 72). This is precisely the point to be reasoned. Alvin Plantinga (2011:ix) is probably correct when he says that there is superficial conflict but deep concord between science and theistic religion, but superficial concord and deep conflict between science and naturalism'.

The religious scholarly market is loaded with publications describing, analysing and offering attempts to resolve this issue - so much so that I refrain from listing even the dozens and dozens of books on library shelves. A relatively recent article by Ted Peters, called, 'Science and Religion: Ten Models of War, Truce, and Partnership' (2017) is worth taking cognisance of here, not only because it provides a balanced oversight of the debate but also because of his proposal of a creative mutual interaction within a framework of theology and nature dialogue. He promotes interaction because he is correct in his thinking that theologians must engage in world view construction (Peters 2017):

Theologians, who reflect rationally on their religious faith, are naturally drawn to the rigors of scientific discourse. Theologians recognize a kindred spirit in scientists in pursuit of discovery, new knowledge, and expansion of our shared worldview. (p. 32)

Against this background, we have to take sincere notification of Alister McGrath's assessment and guidance in his seminal work, The Territories of Human Reason. Science and Theology in an Age of Multiple Rationalities (2019). Based on the biologist's insights of Steven Rose, he affirms that 'I am committed to the view that we live in a world that is an ontological unity, but I must also accept an epistemological pluralism' (McGrath 2019:2, 59). The insight that we obtain about nature is the result of what our methods of investigation disclose to us.

The fact that religion is a social construction with 'little if any, scientific legitimacy' (McGrath 2019:9) makes this debate between theology and science very enriching and promising. The notion of meaning can create such a narrative where disciplinary insights are incorporated into the world of life. This approach is both a 'bottom-up' and 'top-down' approach (very much related to Charles Peirce's abduction notion). This, of course, is then not only a matter of interdisciplinary research but also a matter of transdisciplinary research. McGrath (2019) aptly concludes:

There has been a growing realization that both the beliefs that we hold and the rationality through which we develop and assess these beliefs are embedded in cultural contexts. Rationality is thus increasingly coming to be seen as being dependent (though questions remain about the extent and nature of that dependency) upon its historical and cultural context, and best assessed in terms of the practices it generates. (p. 22)
The insight of McGrath that there is one reason, but multiple rationalities is based on Pierre Duhem's notion of le bon sens, meaning that a given epistemic community is shaped by both intellectual intuitions and biological and social existence (McGrath 2019:39). Seeing that truth is not out there to be discovered, but rather an intellectual and cultural construct (cf. Berger 1992:127-128), we prefer the notion of meaning to truth as the quest of transdisciplinary research.

From this, it should be clear that Ian Barbour's (2005) classical four typologies of the theology and science dialogue presented in his Gifford Lectures (1989-1991)² are very much dated. The current discourse is instead on a meta-level (transversal plane), acknowledging multi-diversity and, subsequently, contingency and, above all, an interconnectedness of reality. This approach recognises, therefore, its limitations and simultaneously opens up scope for mystery. Gabriel $\mathrm{Marcel}^{3}$ taught us that reality has an indefinite number of problems to solve but just as many mysteries to embrace. Celia Deane-Drummond, in her turn, reminds us that a 'theology of nature is appropriate as long as it is suitably qualified by proper attention to revealed theology' (DeaneDrummond 2009:xvi). Science and religion dialogue is one thing, but the one between theology and science is another thing. ${ }^{4}$

The life and work of Pavel Alexandrovich Florensky (18821937) epitomise the contours of this prolegomena rather well, as we shall now see.

\section{Nature in orthodox Christianity}

The extraordinary life and intellectual stature of Florensky are deeply rooted in the rich theological and spiritual tradition of Orthodox Christianity. From Basilio (329-379) to Gregory of Nyssa (335-395), from Gregory of Nazianzen (329-390 ca) to Maximus the Confessor (580-662), the Greek Church Fathers brought about a colossal synthesis between Greek natural philosophy and Christianity in an attempt to conceptualise Nature as the created cosmos. Moving from that legacy of Patristic thought, the Orthodox intellectual vision of the world would be inevitably marked by this double reference: on the one hand, the Hellenism of ancient culture and, on the other hand, the Christianity that has emerged to a significant extent from it.

Although the Greek Church Fathers rejected nothing of the natural science and literature of the ancient pagan Greek world, they emphasised the limited capacities of the human senses and rationality to obtain a complete understanding of physical realities without faith. This remains a distinctive trait of the Christian faith's attitude expressed mainly in the East. In Nature, there always lies a surplus of meaning that 2.Viewed 18 March 2021, from https://www.giffordlectures.org/lecturers/ian-gbarbour.

3.Viewed 18 March 2021, from https://www.giffordlectures.org/lectures/mysterybeing- 0 .

4.Van Rooyen (2016:4) calls this approach the 'Third Dialogue' where Christ is pivotal in the debate. The other two discourses are where humans are central and second where science is widening up. 
remains inaccessible to reason alone and, therefore, Nature should be approached fundamentally with a contemplative approach.

In other words, through faith in God the Creator and in the light of the incarnation, the faithful seek an expansion of their human cognitive capacity to recognise the immanent spiritual dimension in the whole of creation. This gaze remains as the point of reference and the background against which Orthodox theology and spirituality will be articulated over the centuries about Nature.

This thinking made Florensky part of the so-called 'Russian Religious Renaissance' after the 1917 revolution (Moore 2020). The heart of their thinking was that reality is essentially contradictory or an unavoidable 'antinomy'. The challenge for these scholars, and particularly for Florensky, says Moore (2020), is 'to provide an anticipation of the Trinity's vertical antinomy in the horizontal antinomies of logic', where the horizontal has reference to reason and vertical to revelation and dogma.

Since his childhood, Florensky was fascinated by the beauty and organisation of Nature. But what most attracted him was not so much the mechanics and its structure, but rather its mysterious and awe-inspiring aspect. It is truly a 'contemplation' in which his gaze meets that of Nature (with a capital N). He perceived the universe with a solid aesthetic component and mystical overtones (Florenskij ${ }^{5}$ 2009):

Of course, I knew perfectly well that the violet and I had nothing in common, just as I knew that the violet had no eyes [...]. I well remember the sudden and anything but banal sensation of glances that meet, of eyes that stare at each other: something flashes, strong, and then ceases; after all, such a direct observation of the face of Nature could not last for long. Although fleeting, that feeling gave the absolute certainty of the authenticity of the encounter: we had seen each other and we understood each other; and not only did I understand her, but even more she understood me. And I knew that she knew me and saw me even better than I did, and above all I knew that she loved me [...]. Where before there was nothing, suddenly a gaze appeared: now tender, deep and full of expectation towards me, now smart-cheerful, which told me that Nature and I knew what others did not know and should not know. (pp. 127-128)

This passage demonstrates powerfully how much Florensky's relationship with Nature is rooted in his mystagogy. In his perception of reality, the phenomenon, although enlightening, points decisively beyond itself, leading to something greater. However, such a revelation is achieved only through personal love (Florenskij 2009):

Inside me I was convinced, my heart was convinced, that the flowers, my flowers, the ones I loved, loved me in turn and bloomed only for me and that my lack of attention to their beauty would be an offence, an injury, indeed, to their affection for me. (p. 154)

5.Some of the publications of Florensky are only translated into Italian and the spelling is 'Florenskij' in Italian. For the integrity of the bibliography, the authors have decided to maintain both versions.
Thus described, that loving relationship opens up to an original approach to ecology, much in line with that of Laudato $S i$ ' in which Nature 'rather than a problem to be solved, [...] is a joyful mystery to be contemplated with gladness and praise $(\$ 12)^{\prime}$. (Francis Pope 2015). The Pope made us aware that there is a sort of perichoresis of humans and Nature as well.

The place of human beings in his vision becomes of infinite value as he writes (Florenskij 2007):

Both Nature and human beings are infinite, and for this reason their being infinite, and as equipotent, they can be mutually part of each other. I will say more, they can be part of themselves and equipotent parts between themselves and with the whole. Man is part of the world, but at the same time he is as complex as the world is. The world is part of man, but the world is also as complex as man is. (p. 210)

God can be seen as both part of the world and at the same time as transcending the whole reality. 'The absolute being is usually said to be both immanent and transcendent' (Rojek 2019:529). It appears that Florensky uses the concept 'antinomy' and 'contradiction' not consistently and has perhaps something rather like 'paradox' in mind.

Nature is fragmented as a result of original sin, and the implication is that all knowledge is contradictory and antinomic. Rojek (2019:521-522) outlines the three main sources of contradictions in religious discourse, that is, religious experience, theological formulas, and Holy Scripture aptly. At the end of the Sixth Letter of his opus magnum, Florensky (1997:121-123) tables the Christian contradictions: divinity, two natures, relation of God with man, sin, judgement, retribution, final state, deserts, grace, faith and the coming of Christ. The contradiction 'deserts' mentioned deserves a direct quote from the book concerning the thrust of this paper:

Thesis: The necessity of the works of asceticism. (1 Cor 9:24: 'So run, that ye may obtain'.) Antithesis: The lack of necessity of works of asceticism. (Rom 9:16: 'So then it [mercy] is not of him that willeth, nor of him that runneth, but of God that sheweth mercy'.) Thesis: '... work out your own salvation with fear and trembling' (Phil 2:12). Antithesis: 'For it is God which worketh in you both to will and to do of his pleasure' (Phil 2:13). Thesis: Cf. The soul of the Lord desired freely; but it desired freely that which (Antithesis:) it should have desired according to the will of His Father [from 'John of Damascus' Precise Exposition of the Orthodox Faith, 3:18). (p. 122)

\section{Biographical notes ${ }^{6}$ on Pavel Florensky}

Pavel Alexandrovich Florensky was born on 09 January 1882 in Evlach, Azerbaijan, to a Russian father and an Armenian mother. He described his childhood as serene, immersed in the mysterious, wild and fascinating Nature of the Caucasus. A solid reference to scientific thinking marked Pavel's

6.For a formal biography, see Pyman (2010). A more concise version is available on the web by Palini (2017). http://www.fondazionemicheletti.it/altronovecento/articolo. aspx?id_articolo=34\&tipo_articolo=d_persone\&id=145\#sdfootnote19anc. 
upbringing passed onto him, particularly by his father, who somehow sheltered his son from any particular religious education.

During his youth, Pavel showed a great sense of curiosity for nature. It was precisely in that relationship with nature that, alongside the scientific mentality, the fascination for what shone beyond the sensible surface soon emerged in him. Nature itself seemed to teach him, lovingly showing him her truth, beauty, and integrity, as he would describe years later (Florensky 2009):

The matter of the world taught me to love and admire her. And I loved her. However, not the matter of physicists, not the elements of chemistry, not the protoplasm of biology, I loved, but matter herself, with her truth and her beauty, and with her integrity. (p. 97)

After high school, Pavel graduated in Physics and Mathematics from the Moscow State University, where he had studied from 1900 to 1904 . Pavel Florensky researched a thesis that aroused much surprise and interest: On the characteristics of plane curves as places of violation of the principle of continuity (Palini 2017). He was immediately offered the opportunity to continue his research work in the university field. Very soon, he realised that his absolute trust in science proved inadequate to answer the questions of meaning that he asked himself more and more strongly (Florensky 2009):

If before I could not sleep at night, excited by the idea of the next day's experiment, now that the experiment could have been really important and new, now that my intellectual horizon had been broadened and my intellectual habits formed, it had become an incumbency attributable more than anything else to the sense of duty and which only in flashes rekindled enthusiasm. I felt physics and what was connected to it like a suit that was not mine or like a dead skin that had now detached from me. But I didn't dare confess to myself what had happened, and I tried to convince myself that it was a temporary state of mind. (p. 275)

This sense of incompleteness ignited in Florensky the desire for a deeper approach to life that will gradually lead him towards discovering a religious dimension of existence. Thus, he began to engage with the decisive challenge of his life: to conceptualise a synthesis between thought and life, between spirituality and universal culture, which would have culminated with his theological-philosophical masterpiece, The Pillar and Ground of the Truth (2017). ${ }^{7}$ In this opus magnum of Florensky, truth, beauty and goodness are hypostasised in creation.

In 1904, Florensky entered the Theological Academy in Moscow, mainly dealing with Orthodox spirituality and symbolic logic. He did not abandon his interests in mathematics; on the contrary, he tried to investigate even more the relationship between finite and infinite, unity and multiplicity. In this new cultural context, his horizons widen,

7.The book is structured in 12 letters and according to the back cover, dedicated to friend which could be understood symbolically as Christ. However, Kittredge Cherry (2020) published an article based on research (2020) published an article based on research of Giacomo Sanflilippo asserting that this 'friend' was rather Florensky's roommate, Sergei Troitsky, with whom he had 'conjugal friendship'. and his deepest desires are defined: '[ $p$ ]ositivism disgusted me, but no less did abstract metaphysics disgust me. I wanted to see the soul, but I wanted to see it embodied' (Florensky 2009:202). In 1911 he was ordained an Orthodox priest after marrying Anna Giacintova, with whom he had five children and a happy family life.

Florensky actively participated in the cultural life of Moscow with his distinctive intellectual character. His unified vision of the natural world rocked the suffocating materialistic culture of the Communist Party from its foundations, and this exposed him dangerously to the sanctions of the Soviet regime. After the revolution of 1917, the persecutions of Christianity intensified in Russia. Still, Pavel refused exile, as other intellectuals had done, but continued his scientific and cultural commitment by openly displaying his Christian faith. Although initially the regime leveraged Florensky's scientific expertise by commissioning him research for Russia's electrification and other works, eventually, the Stalinist dictatorship would no longer tolerate the faith of the priest-scientist who in 1933 had been arrested and deported to Siberia.

He spent the last three years of his life in a Soviet concentration camp before being fusilladed in 1937. The correspondence of those years with his family reveals, albeit in the drama of an authentic spiritual night, this extraordinary human's spiritual and cultural calibre. In a letter to his son Kirill in 1933 from the concentration camp of Solovki, he wrote (Florensky 2020):

What did I do my whole life? I looked at the world, as a whole, like a united picture and reality, but in every given moment, or to be more exact in every stage of my life, under a certain corner of vision. I looked at the relations of a section of the world in a specific direction, in a specific plane, and tried to understand the construction of the world in this, in the given stage of my study, a sign. The plane of section changed, but one did not replace the other, and only enriched it. Change - an uninterrupted dialectical thought of change of the planes of divergence, with a constant setting on the world as a whole. (p. 231)

And in his spiritual testament, he appeals to the family so that they find in God the only sure reference (Florensky 2018):

I beg you, my dear ones, when you bury me, to take communion on that same day, or if this really is not possible, in the days immediately following. [...] The most important thing I ask you is to remember the Lord and to live before him. With this all I want to tell you is said, the rest are just details or secondary things, but never forget this. (p. 440)

\section{At the heart of the real: the widening of reason}

According to Florensky, the real, the concrete world in which we live, represents a first-rate cognitive challenge. His idea of the real is inseparably connected with the theme of contradiction and mystery. Florensky's thought, with its emphasis on the complexity of reality and ontological symbolism, is configured as a critique of rationalism by 
proposing a new model of reasoning. In line with the Orthodox tradition, Florensky's spirituality and thought is a mystagogy. He does not deny this world's reality but instead invites to enlarge reason to widen up, which only can be perceived by the presence of mystery. For him, under the 'mask' of the visible, there is always an invisible mystery reality (Florensky (2009):

In the meanders of physical reality lies the mystery, which hides behind the corporeal but which is not corporeal, and the corporeal of the mystery not only does not erase the mystery itself, but on certain occasions can even be erased. (p. 225)

Therefore, every authentic scientific attitude towards knowable reality originates from the mystery's perception and the questioning that this arouses interiorly. The enlargement of reason to charity is for Florensky the only way to begin to see and appreciate the world created and 'held in place' by God the Trinity. It is not surprising that Florensky - without wanting to confuse faith and science, religion and philosophy - considers spirituality, understood as the heart's formation, the essential part of gnoseology. To reach and exercise this type of knowledge, a person must practise the 'asceticism' of charity, which allows the heart to manifest itself to its original potential.

The integral understanding of reality represents one of the most characteristic traits of Florensky's thought. For him, the real is constituted of numerous layers ${ }^{8}$ that are interdependent and reciprocally communicating. The antinomy delineates and limits the phenomenal, and the noumenal emerges. In this vision, the outer layers have their foundation in layers below and, therefore, the layer 'on the surface' represents the symbol of the 'hidden' ones. Thus, he asserts, 'this is either a very good antinomism or a very unsuccessful philosophy of integral rationality' (Florensky 1997:116).

Florensky's vision of the real is embedded in the Platonic tradition, where the phenomenon is always a manifestation of the spiritual. Zammit (2019) quotes Florensky:

[...] The spiritual world beyond its own manifestation was understood by me in so far as not-manifested, existing in itself and for itself - not for me. The phenomenon is the substance itself (implied: in its manifestation), the name is the denominated itself (in the measure in which it passes into consciousness and becomes the object of knowledge). But the phenomenon (two-inone spiritual-material), the symbol has always been dear to me in its immediateness, in its concreteness, with its flesh and its soul. In every fibre of its body I saw, I wanted to see, I sought to see, I believed to be able to see the spirit, the only spiritual substance. (p. 39)

As we have seen, contradiction or antinomism plays an integral role in Florensky's thinking. In his opus magnum, Florensky (2017) contends:

8.Take note of Florensky's advanced thinking. McGrath (2019:72-73) writes the following: 'This stratified approach to science and religion is capable of preserving following: 'This stratify's approach to science and religion is capable of preserving and accommodating their complexity and stratification. It recognizes that the natural sciences exist in relationships of interaction and dependency, and that religion is a multi-layered phenomenon which cannot be reduced to any of its communal, symbolic, narrative, or ideational elements' (pp. 72-73).
We then get a powerful contradiction, i.e., at the same time we get:

$\mathrm{A}$ is $\mathrm{A}$;

$\mathrm{A}$ is not $\mathrm{A}$.

Not being in a position to harmonize actively these two parts of one proposition, we are compelled passively to surrender to contradictions that rip apart the consciousness. In affirming one thing, we are compelled at the same moment to affirm the opposite. In affirming the latter, we at once turn to the former. (p. 29)

Florensky (2017:27) believes that truth is subsequently to differentiate between realism and rationalism. 'Truth is the eternal memory of some consciousness. Truth is value worthy of and capable of eternal remembrance' (Florensky 2017:17). The religious consciousness absorbs matters like the two natures of Christ and the one substance but three persons of God. But, says, Moore (2020), these antinomies could only have epistemic justification when based on corresponding anticipatory horizontal antinomies.

Florensky thinks that his understanding of an antinomian truth manifests the revelation through formal logic. This means that 'antimony is the unconditioned objective truth itself', with which Moore (2020) is most uncomfortable. And yet, Foltz (2013:6) believes that the opus magnum of Florensky could be appreciated as the most crucial contribution towards coming to grips with the doctrine of the Trinity since Chalcedon. This is viable, he adds, because this monograph can be read 'as a sustained assault upon the primacy of the law of identity' (Foltz 2013:6).

Florensky subsequently discards rather the priority of the law of identity and not the law itself. The law of identity is based on much more substantial than pure logic (Florensky 2017):

The law of identity, which pretends to absolute universality, turns out to have a place nowhere at all. This law sees its right in its actual givenness, but every given actually rejects this law toto genere, violating it in both the order of space and the order of time - everywhere and always. In excluding all other elements, every $\mathrm{A}$ is excluded by all of them, for if each of these elements is for A only not-A, then A over against not-A is only not-not-A. From the viewpoint of the law of identity, all being, in desiring to affirm itself, actually only destroys itself, becoming a combination of elements each of which is a center of negations, and only negations. Thus, all being is a total negation, one great 'Not'. The law of identity is the spirit of death, emptiness, and nothingness. (p. 59)

This Russian scientist and mystic delineates, therefore, a new understanding of science capable of unifying dichotomies through the notion of a symbol (Florenskij 2009):

All my life I have thought basically about one thing: about the relationship of the phenomena to the noumenon, of its manifestation, its incarnation. I am speaking of the symbol. All my life I have reflected on only one problem, the problem of the symbol. (p. 201) 
Florensky wanted to create a 'syncretic meta-language of theology, science, and art' (Rojek 2019:517). These thoughts lay the table for a tertium datur between rational ontotheology and irrational fideism. One could call this a process of an interactive juxtaposition.

\section{Beyond science - Florensky's criticism of scientism}

Florensky was very much a 'quiet genius' of his time. Able to navigate easily through mathematics, chemistry, physics, engineering, and geology, as well as being well versed in the humanities, his achievements in science are colossal to the point of being dubbed as the Pascal or the Leonardo da Vinci of Russia (Palini 2017:n.p.).

Florensky had quite a critical approach to scientism and rationalism. To his children, he wrote, the law is the authentic fence of Nature, but even the thickest wall has very thin cracks through which the mystery infiltrates (Florensky 2009:243).

For Florensky the function of science is primarily that of providing a symbolic description. At the same time, it would be the task of philosophy - as already outlined by Heraclitus, Plato and more recently Hegel, Fichte and Schelling - to investigate for an explanation of the most intricate mechanisms in phenomena and reality. Science deals with surfaces, with the 'outer shell' of reality and does not deal with reality's mystical internal dimension. Florensky remains convinced that science and philosophy and culture, in general, are based on and serve a fundamental unity, namely, the religious factor, or more precisely, veneration.

Florensky makes a significant conclusion when he says that contradictions fade away at the highest level as they conciliate. 'And, then, in a state of spiritual illumination, there are no contradictions' (Florensky 2017:358). True contradictions appear on the level of reason, but not rationality. The dichotomy of reason is only overcome by a person in spiritual enlightenment, asserts Florensky (2017:59).

Already as a child, Pavel perceives in the wildness of the Georgian countryside the mystery of the transcendence and the unity of Nature (Florenskij 2009):

It was then that I understood the fact that the division of space can only appear such and that, despite the outward appearance, there can be an inner unity that is unity and not unification. (p. 65)

The thoughts of Florensky manifest a truly mystical understanding of the natural world. He is convinced that natural mysticism transcends the fragmentation of the scientific. For him, the former surpasses the latter from within, as though only from within was it possible to affirm the world's substantial unity. For Florensky this is possible without mediation, but as an act of fusion between the soul and the perceived phenomena.

\section{Conclusion}

Florensky's achievements span across different disciplines, from theology to science. His humaneness and spiritual integrity impressed anyone who met him. Sergej Bulgakov observed in commemoration of his missing friend (cited by Misler 2002):

For me Father Pavel was not only a phenomenon of genius, but also a work of art, so harmonious and beautiful was his image. We would need the words, the brush or the chisel of a great master to tell the world about him. (p. 13)

His passionate search for the truth makes him a role model for the people of our time. Florensky was also mentioned by Pope John Paul II in the encyclical Fides et ratio (§ 74) precisely for the original and rigorous way in which he was able to combine the data of scientific knowledge with those of faith (John Paul II Pope 1998:45). Father Florensky can genuinely be a guide and example for that recomposition between secular and religious culture, science and faith for which he spent his thoughts and his life.

Florensky did not seek essentially the how but rather the why of the ultimate meaning of phenomena. McGrath (2019:124) would concur, '[t]here is a significant gap between knowing that and knowing why'. Authentic mysticism lets us see more than the eye can meet ${ }^{9}$ and lets us see within the visible the invisible. The following paragraph ${ }^{10}$ of McGrath (2019) summarises this enterprise appropriately:

We may live in a world that is an ontological unity, but this world is investigated and represented on the basis of an epistemological pluralism, offering us a bricolage of unintegrated insights and perceptions arising from different disciplinary or cultural perspectives on our world, or scientific engagement with its different levels. (pp. 222-223)

Concerning what Peters (2017:33) epitomises as creative mutual interaction (CMI), credit has to be given to this 20th-century Russian priest and mathematician, Pavel Alexandrovich Florensky, for a much-needed epistemic dynamism in his endeavour to construct a rational fit (coherence) between reason and faith and, in the end, the antinomism is but a paradox.

Consequently, the true scientist is obliged to establish their claims on religious convictions. It would be science and not religion that needs to be proven and justified. On the other hand, Florensky considers his scientific ideas as originating from the sense of mystery. He wanted to create an integral vision of reality (which he called 'concrete metaphysics') that could combine theocentric and scientific perspectives, even if his priority would always go to the first. Indeed paradoxical.

9.Ironically, yet deliberately, I use this expression from the works of Richard Dawkins: 'Modern physics teaches us that there is more to truth than meets the eye; or than meets the all too limited human mind...' (Dawkins 2003:19). Obviously, I use this
expression within a different frame of reference.

10.In my humble opinion, this paragraph of McGrath, well-phrased and properly thought-through it is, has the potential to be cited numerously as a synopsis of his whole thinking as did the last paragraph in Darwin's '[On] The Origin of Species' (1859). 


\section{Acknowledgements}

Dr Puglisi expresses his gratitude to have been invited to coauthor in this project, 'Theology and Nature', and thanks Prof. Buitendag for the invitation.

\section{Competing interests}

The authors declare that they have no financial or personal relationships that may have inappropriately influenced them in writing this article.

\section{Authors' contributions}

Both authors contributed equally to this research article.

\section{Ethical considerations}

This article followed all ethical standards for research without direct contact with human or animal subjects.

\section{Funding information}

This research received no specific grant from any funding agency in the public, commercial or not-for-profit sectors.

\section{Data availability}

Data sharing is not applicable to this article as no new data were created or analysed in this study.

\section{Disclaimer}

The views and opinions expressed in this article are those of the authors and do not necessarily reflect the official policy or position of any affiliated agency of the authors.

\section{References}

Barbour, I., 2005, 'Ways of relating science and theology', in R.J. Russel, W.R. Stoege \& G.V. Coyne (eds.), Physics, philosophy and theology, pp. 21-48, Vatican Observatory, Vatican City State.

Berger, P.L., 1992, A far glory: The quest for faith in an age of credulity, Free Press, New York, NY.

Cherry, K., 2020, 'Pavel Florensky and Sergei Troitsky: Russian theologian of same-sex love and his soulmate', Q Spirit, 08 December, 2020, viewed 15 March 2021, from https://qspirit.net/florensky-troitsky-theologian-same-sex-love/.

Dawkins, R., 2003, A devil's chaplain: Selected essays, Orion, Kindle edn.
Deane-Drummond, C., 2009, Christ and evolution: Wonder and wisdom, Fortress Press, Minneapolis, MN.

Florenskij, P., 2009, Ai miei figli: Memorie di giorni passati, Arnoldi Mondadori, Milano.

Florenskij, P.A., 2007, II simbolo e la forma: Scritti di filosofia della scienza, Bollati Boringhieri, Torino.

Florensky, P., 1997, The pillar and ground of the truth: An essay in orthodox theodicy in twelve letters, Princeton University Press, Princeton, NJ, Kindle edn.

Florensky, P., 2018, Non dimenticatemi: Le lettere dal gulag del grande matematico, filosofo e sacerdote russo, Arnoldo Mondadorı, Milano, Kindle edn.

Florensky, P., 2020, Letters from the Gulag, Kindle edn.

Foltz, B., 2013, 'The fluttering of autumn leaves: Metaphysics in Florensky's "the pillar and ground of the truth"', Studia Humana 2(3), 3-18, Viewed 18 March 2021 from http://www.studiahumana.com/pliki/wydania/2(3)-1.pdf.

Francis Pope, 2015, Encyclical Letter LAUDATO SI' of the Holy Father Francis on care for our common home, Vatican Press, Rome, viewed 09 April 2020, from https://w2. vatican.va/content/dam/francesco/pdf/encyclicals/documents/papafrancesco_20150524_enciclica-laudato-si_en.pdf.

John Paul II, Pope, 1998, Encyclical Letter FIDES ET RATIO of The Supreme Pontiff John Paul II to the Bishops of The Catholic Church on the relationship between faith and reason Vatican Press, Rome, viewed 17 March 2021, from http://www.vatican.va/content/ john-paul-ii/en/encyclicals/documents/hf_jp-ii_enc_14091998_fides-et-ratio.html.

McGrath, A.E., 2019, The territories of human reason, Ian Ramsey Centre Studies in Science and Religion, OUP, Oxford, Kindle edn.

Misler, N., 2002, 'Pavel Florensky: A biographical sketch', in N. Misler (ed.), Pavel Florensky - Beyond vision. Essays on the perception of art, Reaktion Books Ltd, London, viewed 20 March 2021, from https://issuu.com/jbfb/docs/pavel florensky-beyond_vision_essa.

Moltmann, J., 2003, Science and wisdom, transl. M. Kohl, Fortress Press, Minneapolis, MN.

Moore, H.J., 2020, 'Antinomism in twentieth-century Russian philosophy: The case of Pavel Florensky', Studies in East European Thought 73, 53-76. https://doi. org/10.1007/s11212-020-09378-y

Numbers, R.L., 2009, 'Aggressors, victims, and peacemakers: Historical actors in the drama of science and religion', in H.W. Attridge (ed.), The religion and science debate. Why does it continue?, The Terry Lectures Series. pp 15-53, Yale University debate. Why does it continue?, The
Press, New Haven, CT, Kindle edn.

Palini, A., 2017, 'Pavel Florensky, a scientist in the Stalinist gulags', Altronovecento 34, viewed 20 March 2021, from http://www.fondazionemicheletti.it/altronovecento/ articolo.aspx?id_articolo=34\&tipo_articolo=d_persone\&id=145\#sdfootnote19anc.

Peters, T., 2017, 'Science and religion: Ten models of war, truce, and partnership', Theology and Science, pp. 1-43, Routledge, Taylor \& Francis, Routledge, viewed 07 December 2017, from https://www.tandfonline.com/doi/full/10.1080/147467 00.2017.1402163.

Plantinga, A., 2011, Where the conflict really lies. Science, religion, \& naturalism, Oxford University Press, Oxford.

Pyman, A., 2010, Pavel Florensky: A quiet genius: The tragic and extraordinary life of Russia's unknown Da Vinci, Bloomsbury Publishing, London.

Rojek, P., 2019, 'Pavel Florensky's theory of religious antinomies', Logica Universalis 13(4), 515-540. https://doi.org/10.1007/s11787-019-00234-0

Thomson, K., 2009, 'Introduction. The religion and science debate: Why does it continue?', in H.W. Attridge (ed.), The religion and science debate. Why does it continue?, pp 1-14, The Terry Lectures Series, Yale University Press, New Haven, CT, Kindle edn.

Van Rooyen, J.A., 2016, 'Why religious human beings need evolutionary epistemology! A theological and evolutionary viewpoint of "why humans need to embrace evolutionary epistemology"', Verbum et Ecclesia 37(1), a1476. https://doi. org/10.4102/ve.v37i1.1476

Volf, M., 2011, A public faith. How followers of Christ should serve the common good, Baker Publishing Group, Grand Rapids, MI, Kindle edn.

Zammit, R., 2019, 'Physics, technology, and theology in Pavel Florensky', Melito Theologica 69/1, 35-46. 